\title{
Oceanobacter-related bacteria are important for the degradation of petroleum aliphatic hydrocarbons in the tropical marine environment
}

\author{
Correspondence \\ Maki Teramoto \\ teramoto-maki@aist.go.jp
}

Received 27 April 2009

Revised 15 June 2009

Accepted 16 June 2009

\author{
Maki Teramoto, ${ }^{1}$ Masahito Suzuki, ${ }^{1}$ Fumiyoshi Okazaki, ${ }^{1}$ Ariani Hatmanti ${ }^{2}$ \\ and Shigeaki Harayama ${ }^{1}$
}

${ }^{1}$ NITE Biotechnology Development Center (NBDC), National Institute of Technology and Evaluation (NITE), 2-5-8 Kazusakamatari, Kisarazu, Chiba 292-0818, Japan ${ }^{2}$ Research Center for Oceanography, Indonesian Institute of Sciences (LIPI), Jakarta Utara 14430,
Indonesia

\begin{abstract}
Petroleum-hydrocarbon-degrading bacteria were obtained after enrichment on crude oil (as a 'chocolate mousse') in a continuous supply of Indonesian seawater amended with nitrogen, phosphorus and iron nutrients. They were related to Alcanivorax and Marinobacter strains, which are ubiquitous petroleum-hydrocarbon-degrading bacteria in marine environments, and to Oceanobacter kriegii (96.4-96.5\% similarities in almost full-length 16S rRNA gene sequences). The Oceanobacter-related bacteria showed high n-alkane-degrading activity, comparable to that of Alcanivorax borkumensis strain SK2. On the other hand, Alcanivorax strains exhibited high activity for branched-alkane degradation and thus could be key bacteria for branched-alkane biodegradation in tropical seas. Oceanobacter-related bacteria became most dominant in microcosms that simulated a crude oil spill event with Indonesian seawater. The dominance was observed in microcosms that were unamended or amended with fertilizer, suggesting that the Oceanobacter-related strains could become dominant in the natural tropical marine environment after an accidental oil spill, and would continue to dominate in the environment after biostimulation. These results suggest that Oceanobacter-related bacteria could be major degraders of petroleum n-alkanes spilt in the tropical sea.
\end{abstract}

\section{INTRODUCTION}

A wide variety of micro-organisms are known to degrade petroleum hydrocarbons (Head et al., 2006; Prince, 2005). Most hydrocarbonoclastic bacteria metabolize either aliphatic or aromatic hydrocarbons, although some bacteria such as strains of Pseudomonas (Whyte et al., 1997) and Rhodococcus (Andreoni et al., 2000) have been shown to degrade both types of hydrocarbons. Among hydrocarbonoclastic bacteria, Alcanivorax (Hara et al., 2003; Kasai et al., 2001; Roling et al., 2004; Yakimov et al., 1998, 2005) and Cycloclasticus (Dyksterhouse et al., 1995; Kasai et al., 2002a; Maruyama et al., 2003) strains have been identified as key micro-organisms in the degradation of aliphatic and aromatic hydrocarbons, respectively, in marine environments (Harayama et al., 2004). Alcanivorax strains are distributed in natural marine environments around the world (Golyshin et al., 2005). The ability of Alcanivorax

Abbreviations: rep-PCR, repetitive extragenic palindromic sequence PCR; T-RF, terminal restriction fragment; T-RFLP, terminal restriction fragment length polymorphism.

The GenBank/EMBL/DDBJ accession numbers for the sequences determined in this work are listed in Table 1. strains to use branched alkanes is high (Hara et al., 2003; McKew et al., 2007), and this could be one of the reasons why these strains predominate in crude-oil-impacted temperate marine environments (Cappello et al., 2007; Hara et al., 2003; Kasai et al., 2001; Roling et al., 2002, 2004; Yakimov et al., 2005). Thalassolituus oleivorans has been reported to degrade aliphatic hydrocarbons (Yakimov et al., 2004), and Thalassolituus strains have recently been shown to dominate in $\mathrm{n}$-alkane-containing temperate seawater microcosms (McKew et al., 2007; Yakimov et al., 2005) and in crude-oil-containing temperate estuarine seawater microcosms (Coulon et al., 2007; McKew et al., 2007).

In addition to these 'professional' hydrocarbonoclastic bacteria, many 'non-professional' hydrocarbonoclastic bacteria such as Marinobacter hydrocarbonoclasticus (Gauthier et al., 1992) have also been isolated. Marinobacter strains (Gauthier et al., 1992; Hedlund et al., 2001; Huu et al., 1999; Sproer et al., 1998) are of increasing interest as many marine hydrocarbonoclastic isolates from various marine environments, including pristine areas, have been suggested to be classified into this genus (González \& Whitman, 2006). 
Variation in seawater temperature has been indicated to select the composition of hydrocarbonoclastic bacteria (Coulon et al., 2007). However, relatively few studies have been conducted on petroleum-hydrocarbon-degrading bacteria in tropical marine environments (Brito et al., 2006; Chaillan et al., 2004; Harwati et al., 2007; Zhuang et al., 2003; Zinjarde \& Pant, 2002). We therefore decided to focus on the petroleum-hydrocarbon-degrading bacteria in the tropical marine environment.

Batch culture techniques have most commonly been used to isolate bacteria that are capable of degrading hydrocarbons of interest. However, this method is highly selective, resulting in the enrichment of a few species with a selective growth advantage under laboratory conditions (Dunbar et al., 1996, 1997; Watanabe et al., 1998). On the other hand, by using alternative methods, such as continuous flow-through culture, dominant bacterial populations in actual environments have successfully been isolated (Kasai et al., 2001, 2002b; Stach \& Burns, 2002; Watanabe et al., 1998). Thus, in the present study, petroleum-hydrocarbon-degrading bacteria in Indonesian seawater were enriched in flow-through cultures containing 'chocolate-mousse' crude oil. We report here on the hydrocarbonoclastic bacteria isolated from these cultures.

\section{METHODS}

Seawater sample. The seawater samples used for isolating petroleum-hydrocarbon-degrading bacteria were collected in June 2006 at Pari Island $\left(5.86^{\circ} \mathrm{S}, 106.62^{\circ}\right.$ E) located off Jakarta, Indonesia.

Preparation of crude oil and of its chocolate mousse. Arabian light crude oil was treated at $214{ }^{\circ} \mathrm{C}$ for $10 \mathrm{~h}$ to remove the volatile fraction (30\% in volume), and used in this study. Chocolate-mousse crude oil was prepared by mixing the crude oil and fresh seawater collected at Pari Island in a ratio of $1: 5(\mathrm{w} / \mathrm{w})$, followed by vigorous and continuous shaking for 1 day. The resultant chocolate mousse was stable for several weeks.

Strains. The reference strain Alcanivorax borkumensis SK2 (ATCC 700651; Yakimov et al., 1998) was obtained from the ATCC; Oceanobacter kriegii strain NBRC 15467 was from NBRC (NITE Biological Resource Center). The strains isolated in this study were deposited in NBRC under numbers NBRC 105758 to NBRC 105769, and also in BTCC (Biotechnology Culture Collection, LIPI, Cibinong, Indonesia) under numbers BTCC B-675 to BTCC B-686.

Continuous-flow culture. One litre of non-sterilized seawater collected at Pari Island was supplemented with $1 \mathrm{~g} \mathrm{NH}_{4} \mathrm{NO}_{3}, 0.2 \mathrm{~g}$ $\mathrm{K}_{2} \mathrm{HPO}_{4}$ and $12 \mathrm{mg} \mathrm{FeCl}_{3}$ (SW medium), and incubated in a glass basin with gentle shaking at room temperature (around $25{ }^{\circ} \mathrm{C}$ ). Three grams of chocolate-mousse crude oil (comprising $0.5 \mathrm{~g}$ crude oil and $2.5 \mathrm{~g}$ seawater) was applied to one side of a pumice stone and floated on the SW medium with the coated side down. SW medium was continuously supplied to the glass basin at a rate of $200 \mathrm{ml}$ per day, while the same amount of the medium was pumped out from the glass basin to maintain the culture volume at $1 \mathrm{l}$. Such continuousflow cultures were conducted in two different modes to isolate hydrocarbon-degrading bacteria of wider diversity. In the first type (culture 1), non-sterilized SW medium prepared with fresh seawater was supplied for the first 10 days, and sterilized SW medium, prepared by autoclaving, was supplied for the next 6 days. In the second type (culture 2), non-sterilized SW medium prepared with fresh seawater was supplied for the first 3 days, and sterilized SW medium was supplied for the next 13 days. On the 16th day after starting the cultivation, the surface of the chocolate-mousse oil and the aqueous phase of the culture were spread onto an SW medium plate $[1.5 \%(\mathrm{w} / \mathrm{v})$ agar; $9 \mathrm{~cm}$ in diameter] covered with $30 \mu \mathrm{l}$ crude oil. The plates were incubated at $18{ }^{\circ} \mathrm{C}$ for up to 6 weeks. The bacterial colonies that appeared on the crude-oil-covered SW medium plates were purified at room temperature (around $25{ }^{\circ} \mathrm{C}$ ) on $\mathrm{dMB}$ plates containing $0.5 \%(\mathrm{w} / \mathrm{v})$ pyruvate. The $\mathrm{dMB}$ plate medium comprised (per litre) $15 \mathrm{~g}$ agar, $0.9 \mathrm{l}$ seawater, $0.1 \mathrm{l}$ distilled water and $3.74 \mathrm{~g}$ Marine broth 2216 (Difco).

Analysis of 16S rRNA genes. Bacterial $16 \mathrm{~S}$ rRNA gene fragments were amplified using primers 27F (5'-AGRGTTTGATCMTGGCTCAG-3'; Vergin et al., 1998) and 1492R (5'-GGYTACCTTGTTACGACTT-3'; Lane, 1991). The PCR was performed in a total volume of $25 \mu \mathrm{l}$ containing 1.25 U Taq DNA polymerase (Ex Taq; Takara), $\mathrm{Mg}^{2+}$-containing buffer supplied with the polymerase ( $2 \mathrm{mM} \mathrm{Mg}^{2+}$ at the final concentration), $1 \mathrm{M}$ betaine (Sigma), $1.25 \mu \mathrm{l}$ DMSO (Sigma), $200 \mu \mathrm{M}$ of each deoxynucleoside triphosphate, $1 \mu \mathrm{M}$ of each primer, and a small amount of bacterial cells that were transferred using a toothpick from a colony that appeared on a plate. The amplification programme was as follows: (i) $5 \mathrm{~min}$ at $94{ }^{\circ} \mathrm{C}$; (ii) 10 touchdown cycles consisting of denaturation for $1 \mathrm{~min}$ at $94{ }^{\circ} \mathrm{C}$, annealing for $1 \mathrm{~min}$ at $65^{\circ} \mathrm{C}$ with the temperature dropping by $1{ }^{\circ} \mathrm{C}$ each cycle, and elongation for $2 \mathrm{~min}$ at $72{ }^{\circ} \mathrm{C}$; (iii) 25 cycles consisting of denaturation for $1 \mathrm{~min}$ at $94{ }^{\circ} \mathrm{C}$, annealing for $1 \mathrm{~min}$ at $55{ }^{\circ} \mathrm{C}$ and elongation for $2 \mathrm{~min}$ at $72{ }^{\circ} \mathrm{C}$; and (iv) a final extension for 7 min at $72{ }^{\circ} \mathrm{C}$. The PCR products were purified with a Qiaquick PCR purification kit (Qiagen) or AMPure (Agencourt). The PCR products were sequenced using a DNA sequencing kit (Dye Terminator Cycle Sequencing kit; Perkin-Elmer) with primers 339F (5'-CTCCTACGGGAGGCAGCAG-3'), 536R (5'-GTATTACCGCGGCTGCTG-3'), 907F (5'-AAACTCAAAGGAATTGACGG-3'), 1510R (5'-GGCTACCTTGTTACGACTT- ${ }^{\prime}$ ') and 27F (5'-AGAGTTTGATCCTGGCTCAG- $3^{\prime}$ ) according to the manufacturer's instructions, and the sequences were determined with a model 3730xl DNA analyser (Applied Biosystems). These sequences were assembled using the ATGC program (version 4.3.0; Genetyx) and compared to those in the GenBank database by using BLAST (Altschul et al., 1990). The alignment of the sequences was done using CLUSTAL_X (version 1.83; Thompson et al., 1997). The distance matrices for the aligned sequences, including all gaps, were calculated, and a neighbourjoining tree (Saitou \& Nei, 1987) was constructed using the NJPlot software in the CLUSTAL_X program.

Rep-PCR. Genomic fingerprints of bacteria were obtained by repetitive extragenic palindromic sequence PCR (rep-PCR) performed with primers REP1R-I and REP2-I (de Bruijn, 1992). The PCR was performed in a total volume of $25 \mu$ l containing $1.25 \mathrm{U}$ Taq DNA polymerase (AmpliTaq Gold; Perkin-Elmer), $10 \mathrm{mM}$ Tris/HCl (pH 8.3), $50 \mathrm{mM} \mathrm{KCl}, 1.5 \mathrm{mM} \mathrm{MgCl}_{2}, 0.001 \%$ (w/v) gelatin, $1 \mathrm{M}$ betaine (Sigma), $1.25 \mu \mathrm{l}$ DMSO (Sigma), $200 \mu \mathrm{M}$ of each deoxynucleoside triphosphate, $1 \mu \mathrm{M}$ of each primer, and a small amount of bacterial cells that were transferred using a toothpick from a colony that appeared on a plate. The PCR conditions used were as follows: $10 \mathrm{~min}$ of polymerase activation at $94{ }^{\circ} \mathrm{C}$, followed by 40 cycles consisting of $1 \mathrm{~min}$ at $94{ }^{\circ} \mathrm{C}, 1 \mathrm{~min}$ at $40{ }^{\circ} \mathrm{C}$ and $8 \mathrm{~min}$ at $65{ }^{\circ} \mathrm{C}$, and finally $10 \mathrm{~min}$ of extension at $72{ }^{\circ} \mathrm{C}$. The PCR products were analysed using a 2100 Bioanalyser (Agilent Technologies). The rep-PCR analysis was conducted twice to determine the reproducibility of the method.

Degradation of crude oil and GC-MS analysis. The SW and $\mathrm{dMB}$ media used for characterizing bacteria were formulated using seawater collected from the Pacific Ocean, $300 \mathrm{~km}$ off the coast of 
Tokyo, Japan. Cells of each bacterium freshly grown on a dMB plate supplemented with $0.5 \%(\mathrm{w} / \mathrm{v})$ pyruvate at room temperature (approx. $25{ }^{\circ} \mathrm{C}$ ) were collected and suspended in filter-sterilized seawater to an $\mathrm{OD}_{600}$ of 0.5 . Then $150 \mu \mathrm{l}$ of this bacterial suspension was inoculated into $3 \mathrm{ml}$ sterilized SW medium supplemented with $3 \mu \mathrm{l}$ crude oil, and this culture was incubated for the indicated period with shaking (200 r.p.m.) at 25 or $30{ }^{\circ} \mathrm{C}$ to examine the crude-oilemulsifying and -degrading abilities. Non-inoculated tubes were similarly incubated and served as controls. Hydrocarbons were extracted twice from the cultures by shaking vigorously with an equal volume of dichloromethane for $1 \mathrm{~min}$. Sodium sulfate was added to the dichloromethane extracts to dehydrate them, and the supernatants were concentrated to approximately $100 \mu \mathrm{l}$ by $\mathrm{N}_{2}$ purging. The concentrated extracts were subjected to GC-MS using a $6890 \mathrm{~A}$ gas chromatograph with a 5973 mass-selective detector (Agilent Technologies) equipped with an Ultra 2 fused silica capillary column (25 $\mathrm{m}$ in length, $0.2 \mathrm{~mm}$ in diameter and $0.33 \mu \mathrm{m}$ in film thickness; HP 19091B-102, Agilent Technologies). The temperatures of the injection port, transfer line, MS source and quadrupole were maintained at $250,250,230$ and $150{ }^{\circ} \mathrm{C}$, respectively. The column temperature was increased from $80{ }^{\circ} \mathrm{C}$ to $320{ }^{\circ} \mathrm{C}$ at a rate of $5{ }^{\circ} \mathrm{C}$ $\min ^{-1}$ for the first $48 \mathrm{~min}$, and then kept at $320{ }^{\circ} \mathrm{C}$ for the next $20 \mathrm{~min}$. Helium was used as the carrier gas at a constant pressure of 20 p.s.i. (138 kPa). To investigate whether a strain degraded alkanes, aromatic compounds, or both, all peak areas for hydrocarbons obtained with the GC-MS selected ion monitoring were normalized by dividing by the peak area for $17 \alpha(H), 21 \beta(H)$-hopane (Prince et al., 1994). For bacteria that could not degrade aromatic hydrocarbons, methyldibenzothiophene instead of $17 \alpha(H), 21 \beta(H)$-hopane was used as the internal standard. The emulsification of crude oil was investigated by visual inspection of crude-oil-containing cultures that had been incubated for 2 weeks.

Substrate utilization analysis. The utilization of carbon sources was tested on ONR7a medium (Dyksterhouse et al., 1995) plates [1.5\% (w/v) Agar Noble (Difco)] supplemented with an appropriate carbon source. The carbon sources were filter-sterilized and added at the final concentration of $0.2 \%$ ( $/ / v$ for solid compounds and $\mathrm{v} / \mathrm{v}$ for liquid compounds). The plates were incubated at $30{ }^{\circ} \mathrm{C}$ for 3 weeks, and the growth was checked by visual inspection.

The GN2 MicroPlate system (Biolog) was used to test for the oxidation of 95 different carbon sources. Cells of each bacterium freshly grown on $\mathrm{dMB}$ plates supplemented with $0.5 \%(\mathrm{w} / \mathrm{v})$ pyruvate at room temperature were collected and suspended in sterilized artificial seawater consisting of $38.39 \mathrm{~g} \mathrm{l}^{-1}$ of artificial sea salt, Marine Art SF1 (Tomita Pharmaceutical). The cell density was adjusted to $20-25 \%$ transmittance by using a Biolog absorbance meter, and $150 \mu$ laliquots were dispensed into each of the 96 wells of the GN2 MicroPlates. The plates were incubated at $30{ }^{\circ} \mathrm{C}$ for 1 week, and the colour change in each well, containing a single carbon source, was scored by visual inspection. Two independent assays were performed for each strain.

PCR detection of alkane monooxygenase gene. The amplification of DNA fragments homologous to alkB and cyp153 was carried out by using the primer sets alkB-1f plus alkB-1r (Kloos et al., 2006) and P450fwl plus P450rv3 (van Beilen et al., 2006), respectively. The reaction mixture was prepared in the same way as described for the analysis of $16 \mathrm{~S}$ rRNA genes. The amplification programme was as follows: (i) 5 min at $94{ }^{\circ} \mathrm{C}$; (ii) 40 cycles consisting of 1 min at $94{ }^{\circ} \mathrm{C}$, $1 \mathrm{~min}$ at $52{ }^{\circ} \mathrm{C}$ and $1 \mathrm{~min}$ at $72{ }^{\circ} \mathrm{C}$; and (iii) a final extension for $7 \mathrm{~min}$ at $72{ }^{\circ} \mathrm{C}$. The amplified DNA fragments were precipitated by ethanol (Sambrook et al., 1989), ligated to the pCR 2.1-TOPO vector (TOPO TA cloning kit; Invitrogen), and introduced into Escherichia coli DH5 $\alpha$ (Toyobo) according to the manufacturer's instructions. Plasmids were isolated from E. coli with the QIAprep Spin Miniprep kit (Qiagen). Sequences of the DNA fragments were determined using
M13 primers as described for the analysis of $16 \mathrm{~S}$ rRNA genes. The DNA sequences were assembled using Sequencher, version 4.8 (Gene Codes Corporation), and compared to those in the GenBank database by using BLAST (Altschul et al., 1990).

Design and operation of beach-simulating microcosms. Microcosms were designed to simulate oil-contaminated sand on a beach. Five hundred grams of sand and $500 \mathrm{ml}$ of seawater collected at Pari Island were placed in each of four stainless steel trays (length, $27 \mathrm{~cm}$; width, $18 \mathrm{~cm}$; depth, $8 \mathrm{~cm}$ ), and left for 1 day. The seawater was then discarded from the trays as much as possible, $50 \mathrm{~g}$ chocolate-mousse crude oil was loaded onto the sand in each of the trays, and the day 0 sample was taken. One or two types of slowrelease fertilizers were then evenly distributed onto the sand in three of the trays, while the fertilizers were not added in the 'control' tray. Fresh seawater $(500 \mathrm{ml})$ was resupplied to each of the trays to start the microcosm experiments. The fertilizers used were either $2 \mathrm{~g}$ per tray of Osmocote 14-14-14 (granules containing $14 \% \mathrm{~N}, 6.1 \% \mathrm{P}$ and $11.6 \% \mathrm{~K}$; Scotts); 2 g per tray of Sumicoat $42-80$ (granules containing $42 \% \mathrm{~N}$; Sumitomo Chemical); or $2 \mathrm{~g}$ per tray of Super IB (Super IBS562; granules containing $15 \%$ N, $7 \%$ P and $10 \%$ K; Mitsubishi Chemical Agri) plus $0.4 \mathrm{~g}$ per tray of Linstar 30 (granules containing $13.1 \%$ P; Mitsubishi Chemical Agri). The seawater in the trays was exchanged with fresh seawater every day by discarding as much as possible of the seawater from the trays and adding $500 \mathrm{ml}$ fresh seawater. These microcosms were maintained at $26-27^{\circ} \mathrm{C}$. $\mathrm{N}$ and $\mathrm{P}$ concentrations in the seawater just before the exchange were measured every 3 to 5 days with a Hach DR/890 portable colorimeter (Hach Company) using Nitrogen, Total Reagent Set, Test 'N Tube (product no. 2672245) and Phosphorus, Total, Test 'N Tube Reagent Set (product no. 2742645), respectively. In the microcosm without fertilizer, total $\mathrm{N}$ in seawater was $0.5 \pm 0.2$ p.p.m. $( \pm \mathrm{SD})$, while total $\mathrm{P}$ was $0.06 \pm 0.03$ p.p.m. throughout the experiment (until day 38). In the Osmocote-supplemented microcosm, total $\mathrm{N}$ dissolved in the seawater was 12 p.p.m. on day 1 and $1.5 \pm 0.6$ p.p.m. from day 4 to day 38 , while total $\mathrm{P}$ was $0.55 \pm 0.31$ p.p.m. throughout the experiment. In the Sumicoat-supplemented microcosm, total $\mathrm{N}$ was 50 p.p.m. on day 1 and $6.1 \pm 3.5$ p.p.m. from day 4 to day 38 , while the level of total $\mathrm{P}$ was almost the same as that in the microcosm without fertilizer. In the Super IB- plus Linstar-supplemented microcosm, total $\mathrm{N}$ was 208 p.p.m. on day 1, and 32.4 p.p.m. on day 4, and this level decreased almost linearly from 10.7 p.p.m. on day 7 to 0.5 p.p.m. on day 29, while total $\mathrm{P}$ was 178 p.p.m. on day 1 , 24.4 p.p.m. on day 4 and $3.79 \pm 2.47$ p.p.m. from day 7 to day 38 . For each sampling, $0.5 \mathrm{~g}$ of the crude-oil-covered sand was taken for analysis of the bacterial community structure, and 3-5 g of the crudeoil-covered sand was taken for the GC-MS analysis using $17 \alpha(H), 21 \beta(H)$-hopane as the internal standard.

Terminal restriction fragment length polymorphism (T-RFLP) analysis. DNA was extracted with 'ISOIL for Beads Beating' (Nippon Gene) from crude-oil-covered sand in the above-mentioned microcosm. Bacteria-specific primers $1492 \mathrm{R}_{\mathrm{MOD}}\left(5^{\prime}\right.$-TACGGYTACCTTGTTAYGACTT-3') and 5' fluorescently labelled (with 6-carboxyfluorescein; Applied Biosystems) 27F $\mathrm{F}_{\mathrm{MOD}}$ (5'-AGRGTTTGATCMTGGCTCAG-3') (Vergin et al., 1998) were used to amplify 16S rRNA gene fragments. The PCR mixture contained, in a total volume of $25 \mu \mathrm{l}, 0.63 \mathrm{U}$ PrimeSTAR HS DNA Polymerase (Takara), $\mathrm{Mg}^{2+}$. containing buffer supplied with the polymerase, $200 \mu \mathrm{M}$ of each deoxynucleoside triphosphate, $0.2 \mu \mathrm{M}$ of each primer and $35 \mathrm{ng}$ of the extracted DNA. The reactions comprised 30 cycles of $10 \mathrm{~s}$ at $98{ }^{\circ} \mathrm{C}, 5 \mathrm{~s}$ at $55{ }^{\circ} \mathrm{C}$ and $90 \mathrm{~s}$ at $72{ }^{\circ} \mathrm{C}$ followed by a final extension of 5 min at $72{ }^{\circ} \mathrm{C}$. Amplification of the PCR products with the expected size was confirmed by electrophoresis through a $1 \%(\mathrm{w} / \mathrm{v})$ agarose gel (LO3; Takara) with $1 \times$ TAE buffer ( $40 \mathrm{mM}$ Tris, $20 \mathrm{mM}$ acetate, $1 \mathrm{mM}$ EDTA, pH 8.0). PCR products were purified with GenElute PCR Clean-Up kit (Sigma). 
The PCR products $(\sim 100 \mathrm{ng})$ for the T-RFLP analysis were digested with $4 \mathrm{U}$ Hhal (Takara) in a total volume of $10 \mu \mathrm{l}$ for $3 \mathrm{~h}$ at $37{ }^{\circ} \mathrm{C}$ with the reaction buffer supplied with the enzyme. The restriction endonuclease was inactivated by heating at $65{ }^{\circ} \mathrm{C}$ for $20 \mathrm{~min}$. Fluorescently labelled terminal restriction fragments (T-RFs) were separated on the basis of size by using an ABI PRISM 3130 genetic analyser (Applied Biosystems) with an internal size standard (GENESCAN-1200 LIZ; Applied Biosystems). T-RFLP electropherograms were analysed by peak area integration of each T-RF (GeneMapper 3.5 software; Applied Biosystems). The percentage fluorescence intensities represented by single T-RFs relative to the total fluorescence intensity of all T-RFs were calculated to obtain a measure of relative $16 \mathrm{~S}$ rRNA gene abundance. The method for the phylogenetic assignment of T-RFs is described in the next section.

Clone library analysis. To analyse the microbial community structure in the microcosm described in the previous section, DNA was extracted with ISOIL for Beads Beating from crude-oil-covered sand in the microcosm with Osmocote on day 29. The $27 \mathrm{~F}_{\mathrm{MOD}}$ and $1492 \mathrm{R}_{\mathrm{MOD}}$ primers were used to amplify $16 \mathrm{~S}$ rRNA gene fragments. The PCR mixture contained, in a total volume of $25 \mu \mathrm{l}, 0.63 \mathrm{U} \mathrm{Taq}$ DNA polymerase (Ex Taq), $\mathrm{Mg}^{2+}$-containing buffer supplied with the polymerase, $200 \mu \mathrm{M}$ of each deoxynucleoside triphosphate, $0.2 \mu \mathrm{M}$ of each primer, $1.25 \mu \mathrm{l}$ DMSO (Sigma), $20 \mu \mathrm{g}$ BSA and $10 \mathrm{ng}$ of the extracted DNA. The PCR conditions were as follows: 3 min at $94{ }^{\circ} \mathrm{C}$, followed by 15 cycles consisting of $1 \mathrm{~min}$ at $94{ }^{\circ} \mathrm{C}$, $1 \mathrm{~min}$ at $50{ }^{\circ} \mathrm{C}$ and $3 \mathrm{~min}$ at $72{ }^{\circ} \mathrm{C}$, and a final extension for $10 \mathrm{~min}$ at $72{ }^{\circ} \mathrm{C}$. Amplification of PCR products was confirmed by electrophoresis through $1 \%(\mathrm{w} / \mathrm{v})$ agarose gel with $1 \times$ TAE buffer. PCR products were purified with the GenElute PCR Clean-Up kit, and the purified PCR products ( $10 \mathrm{ng})$ were cloned into TOPO TA cloning vector (pCR4-TOPO; Invitrogen) and used to transform competent E. coli Mach1-T1 cells (Invitrogen) according to the manufacturer's instructions.

Eighty-two clones were randomly selected from the transformants, and the cloned 16S rRNA gene fragments were amplified using M13 forward (5'-GTAAAACGACGGCCAG-3') and M13 reverse (5'CAGGAAACAGCTATGAC- $3^{\prime}$ ) primers. The PCR mixture contained, in a total volume of $25 \mu \mathrm{l}$, GoTaq Master Mixes (Promega), $1 \mu \mathrm{M}$ of each primer and a small amount of bacterial cells that were transferred from a colony by using a toothpick. The PCR conditions were as follows: $3 \mathrm{~min}$ at $95{ }^{\circ} \mathrm{C}$, followed by 35 cycles consisting of $30 \mathrm{~s}$ at $95{ }^{\circ} \mathrm{C}, 30 \mathrm{~s}$ at $55^{\circ} \mathrm{C}$ and $2 \mathrm{~min}$ at $72{ }^{\circ} \mathrm{C}$, and a final extension for $7 \mathrm{~min}$ at $72{ }^{\circ} \mathrm{C}$. These PCR-amplified 16S rRNA gene fragments were purified with AMPure, and their nucleotide sequences were determined by using the DNA sequencing kit with primers $350 \mathrm{~F}\left(5^{\prime}\right.$ TACGGGAGGCAGCAG-3') and 1100R (5'-AGGGTTGCGCTCGTTG-3'), and the 3730xl DNA analyser according to the manufacturer's instructions. Two sequences obtained with the $350 \mathrm{~F}$ and $1100 \mathrm{R}$ primers were assembled using the ATGC program and the resultant sequences were compared to the GenBank database using BLAST (Altschul et al., 1990). T-RFLP analysis was also performed with each of the representative clones to link their 16S rRNA gene sequences with T-RFs.

\section{RESULTS AND DISCUSSION}

\section{Isolation of petroleum-hydrocarbon-degrading bacteria enriched on crude oil}

Petroleum-hydrocarbon-degrading bacteria were enriched on chocolate-mousse crude oil in a flow-through system in which Indonesian seawater supplemented with nitrogen, phosphorus and iron nutrients was continuously supplied.
After 16 days of cultivation, bacteria were isolated either from the surface of the chocolate-mousse crude oil or from the aqueous phase. Colonies of different morphologies were selected; a total of 60 and 70 isolates were obtained from the surface of the chocolate-mousse crude oil of cultures 1 and 2, respectively, while 20 isolates each were obtained from the aqueous phase of the two cultures. The isolates were grown in SW medium supplemented with $0.1 \%(\mathrm{v} / \mathrm{v})$ crude oil for GC-MS analysis to examine the degradation of petroleum hydrocarbons. The isolates exhibiting significant $\mathrm{n}$-alkane-degrading activity and the isolates exhibiting both n-alkane-degrading and oil-emulsifying activities, a total of 40 isolates, were chosen for further analysis.

\section{Taxonomy of the petroleum-aliphatic- hydrocarbon-degrading isolates}

The 40 isolates were subjected to a rep-PCR analysis for strain typing, and the almost full-length 16S rRNA gene sequence of each of the strains exhibiting distinct rep-PCR patterns was determined (Table 1). In addition to strains of Alcanivorax and Marinobacter, which are ubiquitous petroleum-hydrocarbon-degrading bacteria in marine environments (Golyshin et al., 2005; González \& Whitman, 2006), bacteria related to Oceanobacter kriegii (96.4-96.5\% similarity) were obtained. Since petroleum-hydrocarbon-degrading activity in the genus Oceanobacter has not to our knowledge been reported previously, the activity in O. kriegii NBRC $15467^{\mathrm{T}}$ was examined by incubating the strain for 2 weeks at $30{ }^{\circ} \mathrm{C}$ in SW medium supplemented with $0.1 \%$ (v/v) crude oil. No degradation of petroleum hydrocarbons was detected by GC-MS analysis (data not shown).

A phylogenetic analysis showed that the Alcanivorax strains isolated from Indonesian seawater were not closely related to Alcanivorax borkumensis strain SK2 (Fig. 1). This result was in contrast to that obtained with Japanese seawater using the same enrichment method and temperature conditions: Alcanivorax strains from Japanese seawater are closely related to A. borkumensis SK2 (M. Teramoto and others, unpublished data). This observation may suggest that the SK2-type Alcanivorax strains prefer to inhabit temperate seawater, while tropical seawater is mainly populated by other types of Alcanivorax. Although the genus Alcanivorax is found universally (Golyshin et al., 2005), the geographical distribution of the type of Alcanivorax seems to be biased.

\section{Petroleum-aliphatic-hydrocarbon-degrading abilities of the isolates}

Alkane-degrading activities of the Indonesian isolates were compared at $30{ }^{\circ} \mathrm{C}$ together with A. borkumensis strain SK2 (Fig. 2). Crude-oil-emulsifying activity was detected with all the Alcanivorax strains examined but not with the other alkane-degrading strains examined. The Oceanobacterrelated isolates showed high $\mathrm{n}$-alkane-degrading activities 
Table 1. Taxonomic affiliation of alkane-degrading bacteria obtained in this study, based on almost full-length $16 \mathrm{~S}$ rRNA gene sequences

\begin{tabular}{|c|c|c|}
\hline Isolate $^{\star}$ (accession no.) & Closest GenBank relative $\dagger$ (accession no.) & Similarity $(\%)$ \\
\hline 2A17 (AB435641) & Alcanivorax sp. K3-3 (AB055205) & 98.8 \\
\hline 2A75 (AB435642) & Alcanivorax sp. Mho1 (AB053124) & 100.0 \\
\hline 2A44 (AB435643) & Alcanivorax sp. Haw1 (AB053127) & 99.9 \\
\hline 2lA10 (AB435644) & Alcanivorax sp. CBF L53 (AB166953) & 100.0 \\
\hline 2M3 (AB435645) & Marinobacter hydrocarbonoclasticus (Y16735) & 100.0 \\
\hline $2 \mathrm{M} 46 \ddagger, 2 \mathrm{M} 48 \ddagger(\mathrm{AB} 435646)$ & Alteromonadaceae bacterium LA50 (AF513454) & 99.9 \\
\hline $2 \mathrm{M} 49 \ddagger(\mathrm{AB} 435647)$ & Alteromonadaceae bacterium LA50 (AF513454) & 99.7 \\
\hline $2 \mathrm{M} 26 \ddagger(\mathrm{AB} 435648)$ & Alteromonadaceae bacterium LA50 (AF513454) & 99.8 \\
\hline 2O1\$ (AB435649) & Oceanospirillum sp. ME101 (AJ302699) & 98.2 \\
\hline $1 \mathrm{O} 14 \S(\mathrm{AB} 435650)$ & Oceanospirillum sp. ME101 (AJ302699) & 98.2 \\
\hline $1 \mathrm{O} 18 \$(\mathrm{AB} 435651)$ & Oceanospirillum sp. ME101 (AJ302699) & 98.4 \\
\hline
\end{tabular}

${ }^{\star}$ Another isolate is also given when the isolates have the same sequence of the 16S rRNA gene fragment but show different rep-PCR patterns. The first number ( 1 or 2 ) corresponds to the culture number. The $l$ after the first number shows that the isolate was obtained from the liquid phase, while the others were from the oil surface.

$\dagger$ All closest GenBank relatives belonged to the $\gamma$-Proteobacteria.

$¥$ The validly described bacterial species with the highest 16S rRNA gene sequence similarity was Marinobacter sediminum (AJ609270; 97.1-97.3\% similarity). §The second-closest GenBank relative was Oceanobacter kriegii NBRC 15467 ${ }^{\mathrm{T}}$ (AB006767; 96.4-96.5\%).

that were comparable to A. borkumensis SK2. Alcanivorax strains isolated in this study, except strain $2 l \mathrm{~A} 10$, also exhibited $\mathrm{n}$-alkane-degrading activities as high as $A$. borkumensis SK2. Oceanobacter-related strains, as well as Alcanivorax strains, could thus be important n-alkane degraders in the tropical sea. Marinobacter sp. 2M3 showed the lowest $\mathrm{n}$-alkane-degrading activity, but Marinobacter-

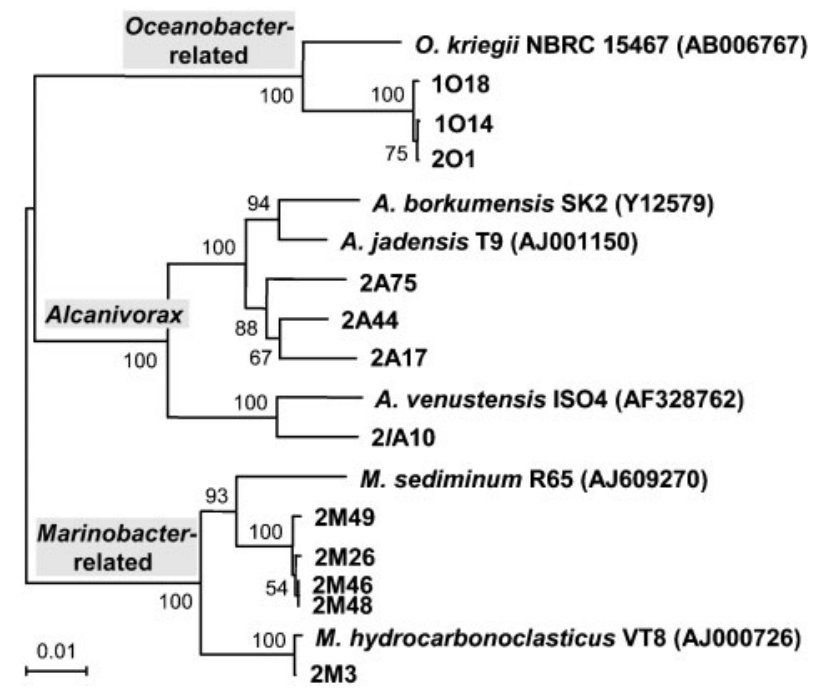

Fig. 1. Phylogenetic relationships based on almost full-length $16 \mathrm{~S}$ rRNA gene sequences of the alkane-degrading strains obtained in this study, their phylogenetically closest type strains and the wellknown alkane-degrading strain Alcanivorax borkumensis SK2. Bootstrap values are indicated at the nodes. The scale bar indicates 0.01 substitutions per site. related (Alteromonadaceae) isolates (2M26, 2M46, 2M48 and 2M49) showed higher n-alkane-degrading activities than Alcanivorax sp. 2lA10.

Concerning the activity for degrading branched alkanes, all the Alcanivorax strains showed significant activity (Fig. 2). In particular, A. borkumensis strain SK2 showed exceptionally high activity for the degradation of branched alkanes. This activity was not significant in Oceanobacter-related or Marinobacter-related strains. Therefore, Alcanivorax strains could be key bacteria for branched-alkane degradation in the tropical sea as well as in the temperate sea (Hara et al., 2003; McKew et al., 2007). Alkane-degrading activities in these strains were also determined at $25{ }^{\circ} \mathrm{C}$ (data not shown). Their activities at $25{ }^{\circ} \mathrm{C}$ were either similar to or lower than those at $30{ }^{\circ} \mathrm{C}$ shown in Fig. 2, and the comparative observations of their activities at $25{ }^{\circ} \mathrm{C}$ were similar to those at $30{ }^{\circ} \mathrm{C}$ described above.

\section{Further characterization of the novel alkane degraders, Oceanobacter-related strains}

In general, the first step in the biodegradation of n-alkanes is catalysed by one of two major alkane-monooxygenase families: AlkB-related integral-membrane diiron proteins and the CYP153 subfamily of cytochrome P450s. Thus, the distribution of alkB and cyp153 in the three Oceanobacterrelated strains 2O1, $1 \mathrm{O} 14$ and $1 \mathrm{O} 18$ was examined. Although no PCR product was amplified with CYP153specific primers, 548 bp DNA fragments homologous to alkB were PCR-amplified from the three Oceanobacterrelated strains. Their deduced amino acid sequences showed $79 \%$ identity to that of alkB2 from Pseudomonas aeruginosa strain DSM1128 (Q6H936). 

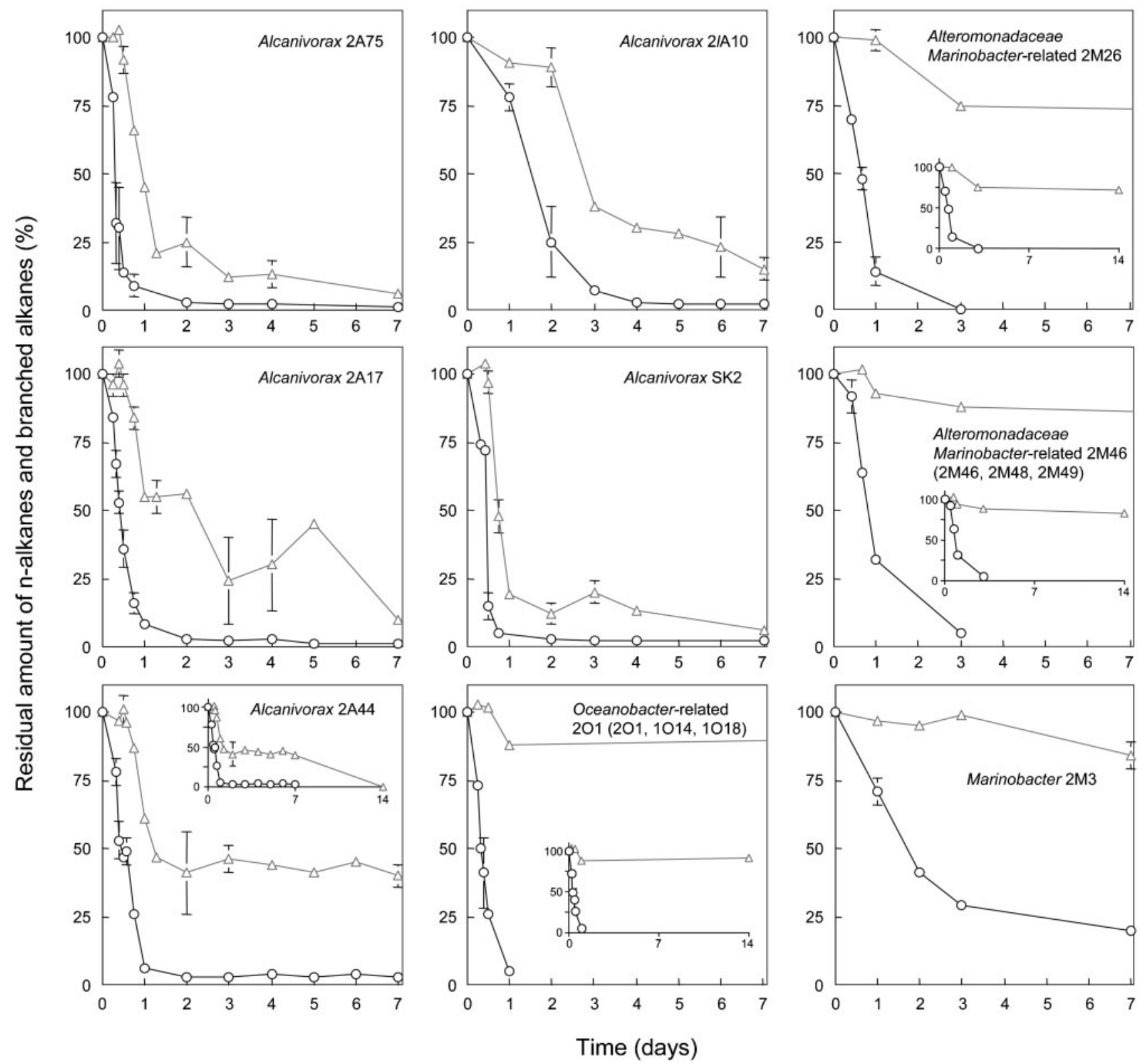

Time (days)

Fig. 2. Degradation of $n$-alkanes and branched alkanes by the alkane-degrading strains at $30{ }^{\circ} \mathrm{C}$. Colonies from each strain grown on $\mathrm{dMB}$ plates supplemented with pyruvate were suspended in filter-sterile seawater until the $\mathrm{OD}_{600}$ was 0.5 . Then $150 \mu \mathrm{l}$ of this bacterial suspension was inoculated into $3 \mathrm{ml} \mathrm{SW}$ medium containing $3 \mu \mathrm{l}$ crude oil, and the culture was incubated for the indicated period at $30{ }^{\circ} \mathrm{C}$. Non-inoculated sterile samples were similarly incubated and served as controls $(100 \%)$. Oil was extracted from the cultures as described in Methods. The n-alkanes $\left(\mathrm{C}_{12-22} ; \bigcirc\right)$ and branched alkanes (pristane and phytane; $\triangle$ ) were quantified. The names of strains that showed similar biodegradation profiles are indicated in parentheses, and the profile of the representative strain is shown. The degradation by Alcanivorax strain SK2 is also shown as a reference. The inset figures show the same data for 14 days incubation. Each value is the mean $\pm S E$ from two independent experiments.

Oceanobacter-related strains 2O1, 1014 and 1018 were able to grow on acetate, pyruvate and propionate but were unable to grow on D-glucose, D-fructose, formate, Larabinose, ribose, glycolate, citrate, DL-lactate, aspartate, Lasparagine or L-proline as a single source of carbon and energy. The Oceanobacter-related strains were shown to oxidize a restricted range of carbon sources by the Biolog GN2 microplate test. Of the 95 different carbon sources, only Tween 40 was oxidized by all three strains. $\beta$ Hydroxybutyric acid, $\gamma$-hydroxybutyric acid and L-glutamic acid were also oxidized by strains $2 \mathrm{O} 1$ and $1 \mathrm{O} 14$; Tween 80 was oxidized only by strain $2 \mathrm{O} 1$. These results 
indicate that Oceanobacter-related strains 2O1, 1014 and $1 \mathrm{O} 18$ are professional hydrocarbonoclastic bacteria.

\section{Dominance of Oceanobacter-related bacteria on crude oil in beach-simulating microcosms using Indonesian seawater}

Crude-oil-contaminated sand was submerged in Indonesian seawater to simulate oil-polluted sand on a beach. Different slow-release fertilizers were added to three such microcosms, while another microcosm was not supplemented with fertilizer. Indonesian seawater in the four microcosms was daily exchanged with fresh seawater for 38 days. The fertilizers used were Osmocote (supplying $\mathrm{N}$ and $\mathrm{P}$ ), Sumicoat (supplying $\mathrm{N}$ ) and Super IB/Linstar (supplying $\mathrm{N}$ and $\mathrm{P} /$ supplying $\mathrm{P}$ ).

The T-RFLP analyses of crude oil in these microcosms indicated that a 362 bp T-RF became dominant in all the four microcosms, although this T-RF was minor at day 0 (Fig. 3). The comparison between T-RFs from the microcosms (Fig. 3) and the $16 \mathrm{~S}$ rRNA gene clone library (Table 2) showed that the dominant $362 \mathrm{bp}$ T-RF band corresponded to Oceanobacter-related strains. These results suggest that Oceanobacter-related strains could dominate in the natural tropical marine environment after an accidental oil spill, and would continue to dominate in the environment after biostimulation. Together with the observation that Oceanobacter-related strains showed high n-alkane-degrading activity (Fig. 2), these findings strongly suggest that Oceanobacter-related bacteria could be major degraders of petroleum n-alkanes accidentally spilt in tropical seas. On the other hand, Alcanivorax (Cappello et al., 2007; Hara et al., 2003; Kasai et al., 2001; Roling et al., 2002, 2004; Yakimov et al., 2005) and Thalassolituus (Coulon et al., 2007; McKew et al., 2007) strains have been reported to dominate in crude-oilcontaining temperate seawater and temperate estuarine seawater, respectively. Oceanobacter-related bacteria may prefer oil surfaces, while A. borkumensis was dominantly present on heavy oil remaining on a Japanese beach after the Nakhodka tanker oil-spill accident (Kasai et al., 2001). Thus, the type of bacteria important for the bioremediation of oil-polluted marine environments would be different depending on the climate. Rich microbial resources including hydrocarbon-degrading bacteria must be harboured in tropical marine environments (Harwati et al., 2007). Accordingly, other aliphatic-hydrocarbonconsuming bacteria would be able to enter the game in tropical marine environments and this may have caused the difference in bacterial types which are important for the bioremediation of petroleum hydrocarbons in marine environments.

\section{ACKNOWLEDGEMENTS}

We thank Hideka Maeda for GC-MS operation, and Kozue Anzai and Rieko Suzuki for sequencer operation. We also thank Atsushi

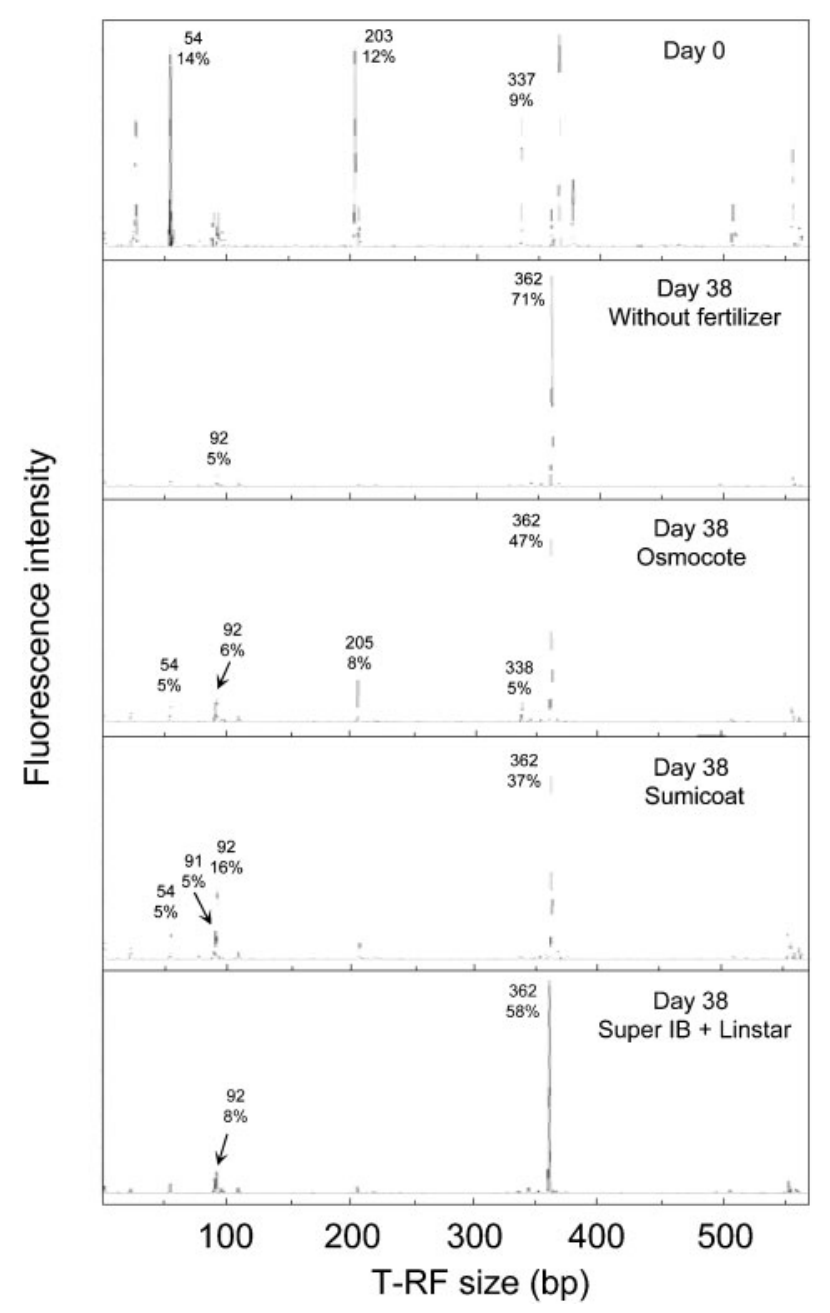

Fig. 3. T-RFLP profiles from microcosms simulating oil-polluted sand on a beach. Three microcosms were supplemented with one or two kinds of slow-release fertilizers (Osmocote, Sumicoat and Super IB/Linstar: see text for details), while one microcosm was not treated with fertilizer. Profiles of day 0 samples from each of the four microcosms were similar, and one representative profile is shown. Sizes of T-RFs with a fragment frequency of $5 \%$ or more and identified in the 16S rRNA gene clone library (Table 2) are indicated. The residual amount of $n$-alkanes $\left(\mathrm{C}_{11-30}\right)$ of the crude oil on day 38 was about $75 \%$ in the microcosm without fertilizer, $25 \%$ with Osmocote, $55 \%$ with Sumicoat and $55 \%$ with Super IB/Linstar, with day 0 samples as the controls (100\%).

Yamazoe for advice on the clone library analysis, Koji Mori for advice on the phylogenetic analysis, and Yeti Darmayati for helping to obtain bacteria in Indonesia. We appreciate the support of Ruyitno and Yantyati Widyastuti, who permitted this work with Indonesian marine resources. This work was conducted under the Joint Research Project between the Department of Biotechnology, National Institute of Technology and Evaluation, Japan, and the Indonesian Institute of Sciences (LIPI), and was supported by a grant (P05032) from the New Energy and Industrial Technology Development Organization (NEDO). 
Table 2. Distribution of the bacterial phylotypes in the 16S rRNA gene clone library from the Osmocote-supplemented microcosm on day 29 , and their corresponding T-RFs

\begin{tabular}{|c|c|c|c|c|}
\hline \multirow[t]{2}{*}{ No. of clones* } & \multicolumn{2}{|c|}{ Closest GenBank relative } & \multirow{2}{*}{$\begin{array}{c}\text { Similarity } \\
(\%) \dagger\end{array}$} & \multirow{2}{*}{$\begin{array}{c}\text { Size of T-RF } \\
\text { (bp) }\end{array}$} \\
\hline & Phylogenetic group & Strain, species, or clone (accession no.) & & \\
\hline $31(38 \%) \ddagger$ & $\gamma$-Proteobacteria & Oceanospirillum sp. ME101 (AJ302699) & 96.0 & 362 \\
\hline $6(7 \%) \S$ & $\alpha$-Proteobacteria & Marine strain B50 (AB302372) & 100.0 & 54 \\
\hline $2(2 \%)$ & $\gamma$-Proteobacteria & Marinobacter vinifirmus (DQ768655) & 100.0 & 205 \\
\hline $1(1 \%)$ & $\gamma$-Proteobacteria & Alteromonas sp. 46Xb1 (EU440052) & 100.0 & 203 \\
\hline $1(1 \%)$ & $\delta$-Proteobacteria & Desulfospira joergensenii (X99637) & 95.4 & 92 \\
\hline $1(1 \%)$ & $\delta$-Proteobacteria & Desulfobacterium zeppelinii (EF442983) & 94.7 & 92 \\
\hline $1(1 \%)$ & $\delta$-Proteobacteria & Marine sulfate-reducing strain WN (U51844) & 97.0 & 92 \\
\hline $1(1 \%)$ & $\delta$-Proteobacteria & Desulfobacterium cetonicum (AJ237603) & 93.9 & 91 \\
\hline $1(1 \%)$ & $\delta$-Proteobacteria & Desulfocapsa sp. La4.1 (AF228119) & 95.6 & 91 \\
\hline $1(1 \%)$ & $\alpha$-Proteobacteria & Roseobacter sp. NT N37 (AB166982) & 97.2 & 54 \\
\hline $1(1 \%)$ & $\alpha$-Proteobacteria & Shimia marina (AY962292) & 99.2 & 54 \\
\hline
\end{tabular}

*Eighty-two clones were analysed in total. Information on the clones with a T-RF with fragment frequency of $5 \%$ or more detected by T-RFLP analysis is provided. Each of the remaining 24 clones, which are not on the list, constituted less than $4 \%$ of the library.

$\dagger$ Identity values are based on 602-684 sequenced base pairs.

$¥$ The second-closest GenBank relative was Oceanobacter kriegii NBRC 15467 ${ }^{\mathrm{T}}$ (AB006767; 95.3\%).

\$The validly described bacterial species with the highest $16 \mathrm{~S}$ rRNA gene sequence similarity was Thalassobius mediterraneus (AJ878874; $98.3 \%$ similarity).

\section{REFERENCES}

Altschul, S. F., Gish, W., Miller, W., Myers, E. W. \& Lipman, D. J. (1990). Basic local alignment search tool. J Mol Biol 215, 403-410.

Andreoni, V., Bernasconi, S., Colombo, M., van Beilen, J. B. \& Cavalca, L. (2000). Detection of genes for alkane and naphthalene catabolism in Rhodococcus sp. strain 1BN. Environ Microbiol 2, 572-577.

Brito, E. M., Guyoneaud, R., Goni-Urriza, M., Ranchou-Peyruse, A., Verbaere, A., Crapez, M. A., Wasserman, J. C. \& Duran, R. (2006). Characterization of hydrocarbonoclastic bacterial communities from mangrove sediments in Guanabara Bay, Brazil. Res Microbiol 157, $752-762$.

Cappello, S., Caruso, G., Zampino, D., Monticelli, L. S., Maimone, G., Denaro, R., Tripodo, B., Troussellier, M., Yakimov, M. \& Giuliano, L. (2007). Microbial community dynamics during assays of harbour oil spill bioremediation: a microscale simulation study. J Appl Microbiol 102, 184-194.

Chaillan, F., Le Fleche, A., Bury, E., Phantavong, Y. H., Grimont, P., Saliot, A. \& Oudot, J. (2004). Identification and biodegradation potential of tropical aerobic hydrocarbon-degrading microorganisms. Res Microbiol 155, 587-595.

Coulon, F., McKew, B. A., Osborn, A. M., McGenity, T. J. \& Timmis, K. N. (2007). Effects of temperature and biostimulation on oildegrading microbial communities in temperate estuarine waters. Environ Microbiol 9, 177-186.

de Bruijn, F. J. (1992). Use of repetitive (repetitive extragenic palindromic and enterobacterial repetitive intergeneric consensus) sequences and the polymerase chain reaction to fingerprint the genomes of Rhizobium meliloti isolates and other soil bacteria. Appl Environ Microbiol 58, 2180-2187.

Dunbar, J., Wong, D., Yarus, M. J. \& Forney, L. J. (1996). Autoradiographic method for isolation of diverse microbial species with unique catabolic traits. Appl Environ Microbiol 62, 4180-4185.

Dunbar, J., White, S. \& Forney, L. (1997). Genetic diversity through the looking glass: effect of enrichment bias. Appl Environ Microbiol 63, 1326-1331.

Dyksterhouse, S. E., Gray, J. P., Herwig, R. P., Lara, J. C. \& Staley, J. T. (1995). Cycloclasticus pugetii gen. nov., sp. nov., an aromatic hydrocarbon-degrading bacterium from marine sediments. Int J Syst Bacteriol 45, 116-123.

Gauthier, M. J., Lafay, B., Christen, R., Fernandez, L., Acquaviva, M., Bonin, P. \& Bertrand, J. C. (1992). Marinobacter hydrocarbonoclasticus gen. nov., sp. nov., a new, extremely halotolerant, hydrocarbondegrading marine bacterium. Int J Syst Bacteriol 42, 568-576.

Golyshin, P. N., Harayama, S., Timmis, K. N. \& Yakimov, M. M. (2005). Family Alcanivoraceae. In Bergey's Manual of Systematic Bacteriology, 2nd edn, vol. 2. pp. 295-299. Edited by G. M. Garrity. New York: Springer.

González, J. M. \& Whitman, W. B. (2006). Oceanospirillum and related genera. In The Prokaryotes. Proteobacteria: Gamma subclass, 3rd edn, vol. 6. pp. 887-915. Edited by M. Dworkin, S. Falkow, E. Rosenberg, K.-H. Schleifer \& E. Stackebrandt. New York: Springer.

Hara, A., Syutsubo, K. \& Harayama, S. (2003). Alcanivorax which prevails in oil-contaminated seawater exhibits broad substrate 
specificity for alkane degradation. Environ Microbiol 5, 746753.

Harayama, S., Kasai, Y. \& Hara, A. (2004). Microbial communities in oil-contaminated seawater. Curr Opin Biotechnol 15, 205-214.

Harwati, T. U., Kasai, Y., Kodama, Y., Susilaningsih, D. \& Watanabe, K. (2007). Characterization of diverse hydrocarbondegrading bacteria isolated from Indonesian seawater. Microbes Environ 22, 412-415.

Head, I. M., Jones, D. M. \& Roling, W. F. (2006). Marine microorganisms make a meal of oil. Nat Rev Microbiol 4, 173-182.

Hedlund, B. P., Geiselbrecht, A. D. \& Staley, J. T. (2001). Marinobacter strain NCE312 has a Pseudomonas-like naphthalene dioxygenase. FEMS Microbiol Lett 201, 47-51.

Huu, N. B., Denner, E. B., Ha, D. T., Wanner, G. \& Stan-Lotter, H. (1999). Marinobacter aquaeolei sp. nov., a halophilic bacterium isolated from a Vietnamese oil-producing well. Int J Syst Bacteriol 49, 367-375.

Kasai, Y., Kishira, H., Syutsubo, K. \& Harayama, S. (2001). Molecular detection of marine bacterial populations on beaches contaminated by the Nakhodka tanker oil-spill accident. Environ Microbiol 3, 246255.

Kasai, Y., Kishira, H. \& Harayama, S. (2002a). Bacteria belonging to the genus Cycloclasticus play a primary role in the degradation of aromatic hydrocarbons released in a marine environment. Appl Environ Microbiol 68, 5625-5633.

Kasai, Y., Kishira, H., Sasaki, T., Syutsubo, K., Watanabe, K. \& Harayama, S. (2002b). Predominant growth of Alcanivorax strains in oil-contaminated and nutrient-supplemented sea water. Environ Microbiol 4, 141-147.

Kloos, K., Munch, J. C. \& Schloter, M. (2006). A new method for the detection of alkane-monooxygenase homologous genes $($ alkB) in soils based on PCR-hybridization. J Microbiol Methods 66, 486-496.

Lane, D. J. (1991). 16S/23S rRNA sequencing. In Nucleic Acid Techniques in Bacterial Systematics, pp. 115-175. Edited by E. Stackebrandt \& M. Goodfellow. Chichester, UK: Wiley.

Maruyama, A., Ishiwata, H., Kitamura, K., Sunamura, M., Fujita, T., Matsuo, M. \& Higashihara, T. (2003). Dynamics of microbial populations and strong selection for Cycloclasticus pugetii following the Nakhodka oil spill. Microb Ecol 46, 442-453.

McKew, B. A., Coulon, F., Osborn, A. M., Timmis, K. N. \& McGenity, T. J. (2007). Determining the identity and roles of oil-metabolizing marine bacteria from the Thames estuary, UK. Environ Microbiol 9, $165-176$.

Prince, R. C. (2005). The microbiology of marine oil spill bioremediation. In Petroleum Microbiology, pp. 317-335. Edited by B. Ollivier \& M. Magot. Washington, DC: American Society for Microbiology.

Prince, R. C., Elmendorf, D. L., Lute, J. R., Hsu, C. S., Haith, C. E., Senius, J. D., Dechert, G. J., Douglas, G. S. \& Butler, E. L. (1994). $17 \alpha(H), 21 \beta(H)$-hopane as a conserved internal marker for estimating the biodegradation of crude oil. Environ Sci Technol 28, 142-145.

Roling, W. F., Milner, M. G., Jones, D. M., Lee, K., Daniel, F., Swannell, R. J. \& Head, I. M. (2002). Robust hydrocarbon degradation and dynamics of bacterial communities during nutrient-enhanced oil spill bioremediation. Appl Environ Microbiol 68, 5537-5548.

Roling, W. F., Milner, M. G., Jones, D. M., Fratepietro, F., Swannell, R. P., Daniel, F. \& Head, I. M. (2004). Bacterial community dynamics and hydrocarbon degradation during a field-scale evaluation of bioremediation on a mudflat beach contaminated with buried oil. Appl Environ Microbiol 70, 2603-2613.

Saitou, N. \& Nei, M. (1987). The neighbor-joining method: a new method for reconstructing phylogenetic trees. Mol Biol Evol 4, 406425.

Sambrook, J., Fritsch, E. F. \& Maniatis, T. (1989). Molecular Cloning: a Laboratory Manual, 2nd edn. Cold Spring Harbor, NY: Cold Spring Harbor Press.

Sproer, C., Lang, E., Hobeck, P., Burghardt, J., Stackebrandt, E. \& Tindall, B. J. (1998). Transfer of Pseudomonas nautica to Marinobacter hydrocarbonoclasticus. Int J Syst Bacteriol 48, 1445-1448.

Stach, J. E. \& Burns, R. G. (2002). Enrichment versus biofilm culture: a functional and phylogenetic comparison of polycyclic aromatic hydrocarbon-degrading microbial communities. Environ Microbiol 4, 169-182.

Thompson, J. D., Gibson, T. J., Plewniak, F., Jeanmougin, F. \& Higgins, D. G. (1997). The CLUSTAL_X Windows interface: flexible strategies for multiple sequence alignment aided by quality analysis tools. Nucleic Acids Res 25, 4876-4882.

van Beilen, J. B., Funhoff, E. G., van Loon, A., Just, A., Kaysser, L., Bouza, M., Holtackers, R., Rothlisberger, M., Li, Z. \& Witholt, B. (2006). Cytochrome P450 alkane hydroxylases of the CYP153 family are common in alkane-degrading eubacteria lacking integral membrane alkane hydroxylases. Appl Environ Microbiol 72, 59-65.

Vergin, K. L., Urbach, E., Stein, J. L., DeLong, E. F., Lanoil, B. D. \& Giovannoni, S. J. (1998). Screening of a fosmid library of marine environmental genomic DNA fragments reveals four clones related to members of the order Planctomycetales. Appl Environ Microbiol 64, 3075-3078.

Watanabe, K., Teramoto, M., Futamata, H. \& Harayama, S. (1998). Molecular detection, isolation, and physiological characterization of functionally dominant phenol-degrading bacteria in activated sludge. Appl Environ Microbiol 64, 4396-4402.

Whyte, L. G., Bourbonniere, L. \& Greer, C. W. (1997). Biodegradation of petroleum hydrocarbons by psychrotrophic Pseudomonas strains possessing both alkane (alk) and naphthalene (nah) catabolic pathways. Appl Environ Microbiol 63, 3719-3723.

Yakimov, M. M., Golyshin, P. N., Lang, S., Moore, E. R., Abraham, W. R., Lunsdorf, H. \& Timmis, K. N. (1998). Alcanivorax borkumensis gen. nov., sp. nov., a new, hydrocarbon-degrading and surfactantproducing marine bacterium. Int J Syst Bacteriol 48, 339-348.

Yakimov, M. M., Giuliano, L., Denaro, R., Crisafi, E., Chernikova, T. N., Abraham, W.-R., Luensdorf, H., Timmis, K. N. \& Golyshin, P. N. (2004). Thalassolituus oleivorans gen. nov., sp. nov., a novel marine bacterium that obligately utilizes hydrocarbons. Int $J$ Syst Evol Microbiol 54, 141-148.

Yakimov, M. M., Denaro, R., Genovese, M., Cappello, S., D'Auria, G., Chernikova, T. N., Timmis, K. N., Golyshin, P. N. \& Giluliano, L. (2005). Natural microbial diversity in superficial sediments of Milazzo Harbor (Sicily) and community successions during microcosm enrichment with various hydrocarbons. Environ Microbiol 7, 1426-1441.

Zhuang, W. Q., Tay, J. H., Maszenan, A. M. \& Tay, S. T. (2003). Isolation of naphthalene-degrading bacteria from tropical marine sediments. Water Sci Technol 47, 303-308.

Zinjarde, S. S. \& Pant, A. A. (2002). Hydrocarbon degraders from tropical marine environments. Mar Pollut Bull 44, 118-121.

Edited by: D. J. Arp 